\title{
Organic Matter Effects on Some Geotechnical Properties of Cohesive Soils in Selected Areas of Basrah Governorate/Southern Iraq
}

\author{
Alaa Mohsin Khalaf*, Asst. Prof. Rai'd Aziz Mahmood (Ph.D.) \\ Department of Geology - College of Science - University of Basra, Basrah, Iraq
}

*Corresponding Author: Alaa Mohsin Khalaf, Department of Geology - College of Science - University of Basra, Basrah, Iraq

\begin{abstract}
Soils with high organic content, which are called organic soils are one of the soil types that causes many problems for engineering construction. In this study, a sample has been taken from Hayy-Al-Hussein site and measuring their organic content. To identify the behavior of some geotechnical properties of cohesive soil in the presence of different organic content, animal manure is added to soil to make a mixture of soils having 1, 2, 3 and $4 \%$ of the organic matter. The natural soil and these four samples are prepared and performing the geotechnical test such as Atterberg limits, unconfined compressive strength, and direct shear strength. The result showed that there is increase in Atterberg limits (liquid limit, plastic limit, and plasticity index) with an increase of the organic matter content, while the cohesion values decrease from 36 $\mathrm{kPa}$ in the natural soil to $18 \mathrm{kPa}$ in treated soil having $4 \%$ of organic matter and the values of the angle of internal friction reaches 14 and 12 degrees in the 1 and $2 \%$ of the organic matter added and then decreased to reach 6 degrees in the $4 \%$ of the organic matter added. The unconfined compressive strength also decreased from $713.37 \mathrm{kPa}$ in the natural soil to $540.23 \mathrm{kPa}$ at the same above values $4 \%$ of organic matter.
\end{abstract}

Keywords: Organic matter, Basrah soils, Animal manure, Geotechnical properties.

\section{INTRODUCTION}

Organic soils are consist of plants and animal remains, fresh and at various stages of decomposition (Soil Science Society of America, 1979). The organic soils comprise all the organic matter present in soils regardless of its origin or decomposition state. It includes living organic matter (plants, microbial biomass, and faunal biomass), dissolved organic matter, particulate organic matter, humus, and highly carbonized organic matter (Baldock and Skjemstad, 1999). The organic soils are naturally rich with organic matter that contains a significant amount of Carbon (C), Hydrogen (H), Oxygen (O), Nitrogen $(\mathrm{N})$, Phosphorous (P) and Sulphur (S). The soils that contain more than $2 \%$ of organic matter are called "organic soil", even with low content of organic matter in soil (1 - $3 \%)$ that can classify soil into different groups, therefore it indicates the high activity of the organic matter to change the geotechnical properties of the soil (Myslinska, 2010). The organic soils have a large void ratio that is formed due to the decomposition of organic matter in the soil. Therefore, this type of soils is unsuitable for the embankments and highway fills (U.S.D.I, 1965 in Mahmood, 1997). The organic matter in soils had a significant effect on foundations due to the high organic content that prevents cement from consolidation and high sulfate content which caused crashing of the concrete. In general, less than $0.5 \%$ of the organic matter in the soil is unlikely to affect the engineering behavior, while 2 $\%$ to $3 \%$ of the organic matter seriously alters the strength and compressibility of the soil (Scott, 1980). Booth and Dahl (1986) estimated that the ratio of $2 \%$ of the organic carbon that equals $3.44 \%$ of the organic matter is value-affecting engineering soil behavior. This study focuses on indicating the allowable limits of organic content that influence the geotechnical properties of soil by adding different percentages of natural organic matter and measuring their effect on some geotechnical properties among the study area soil such as Atterberg limits, unconfined compression strength, cohesion and the angle of internal friction. 


\section{Materials AND Methodology}

\subsection{Sample Preparing}

In this study disturbed sample is taken from Hayy-Al-Hussein site within the first-meter depth and measuring their organic content. It contains 0.1 percent of the organic matter. To identify the allowable limits of the organic matter that affecting the geotechnical properties of cohesive soil such as Atterberg limits, unconfined compression strength, and direct shear test the animal manure that available in local markets was adopted. The animal manure passes through No.40 sieve to remove coarse particles and mixed with soil sample in the required proportions to make mixtures from the organic content 1,2, 3 and $4 \%$. After that, each mixture is placed in a plastic bag and left 7 days for a curing period before performing the required tests.

\subsection{The Tests used in the Study}

To achieve the objects of the study, the tests are accomplished to determine the allowable limits of organic content that influence the geotechnical properties of Basrah soil. The Atterberg limits tests were carried out according to ASTM D- 4318-05. This test is used to detect the water content of fine grain soils and classify the soils according to the Unified Soil Classification System (USCS). While Unconfined compressive strength test is accomplished by using the re-molding method with $15 \times 7.5$ $\mathrm{cm}$ dimensional. The remolded samples are prepared according to ASTM (D-1883). The test was conducted according to ASTM D- 2166 and the Direct shear test are prepared by using the re-molding method with $6 \times 6 \mathrm{~cm}$ cubic dimensional. The examination is carried out according to ASTM D - 3080 .

\section{RESUlTS AND DISCUSSIONS}

\subsection{Atterberg Limits Tests}

The results of the test show the liquid limit for the natural and treated soil samples are 40, 41.2, 43.5, 46.6 and $48 \%$, respectively, as shown in Figure 1. These results demonstrate that there is an increase in the liquid limit values with increasing organic content, ranging from $40 \%$ in the natural soil to $48 \%$ in the soil with $4 \%$ of organic content. While the values of the plasticity index for the natural soil and treated samples are 17.3, 19.9,20.6,23.4 and 28.3, respectively, as shown in Figure2. The results show that there is a high increase in the values of the plasticity index with increasing organic content, ranging from $17.3 \%$ in the natural soil to $28.3 \%$ in the soil with $4 \%$ organic matter.

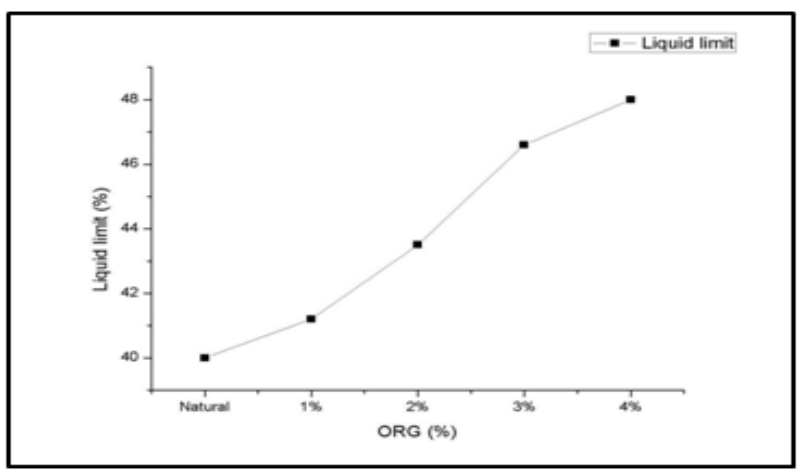

Figure1. Liquid limit virus different organic matter content relationship

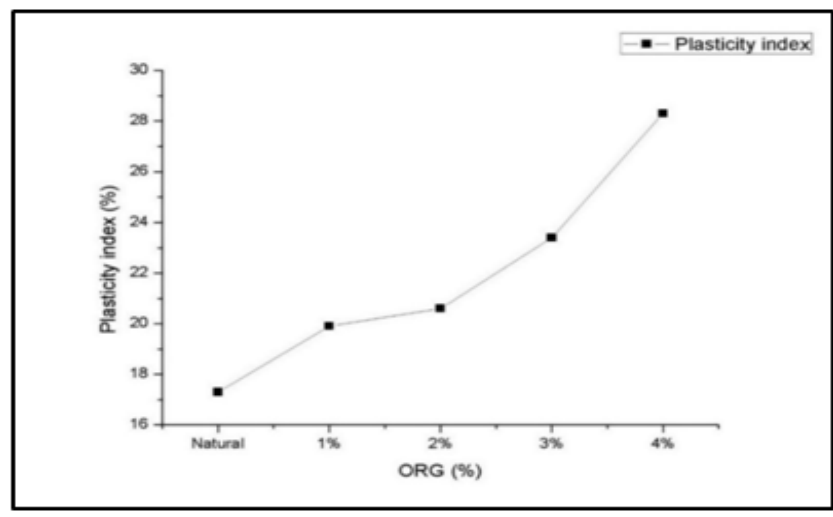

Figure2. Plasticity index virus different organic matter content 
There is an increase in both liquid limit and plasticity index with increasing organic content. This increase is due to the fibrous structure of the organic matter that contains more voids inside its internal structure, which has a high water absorption capacity (Warrick, 2002).

The plasticity chart for the natural and treated soils in Figure 3 shows that with increasing the organic matter content, the position of soils is plotted below the A-line. It is classified as low plasticity silty clay (CL) in the natural soil and $1 \%$ of the organic matter added, while it is classified as low plasticity silt and organic soils (ML\&OL) in the 2,3 and $4 \%$ of the organic matter added.

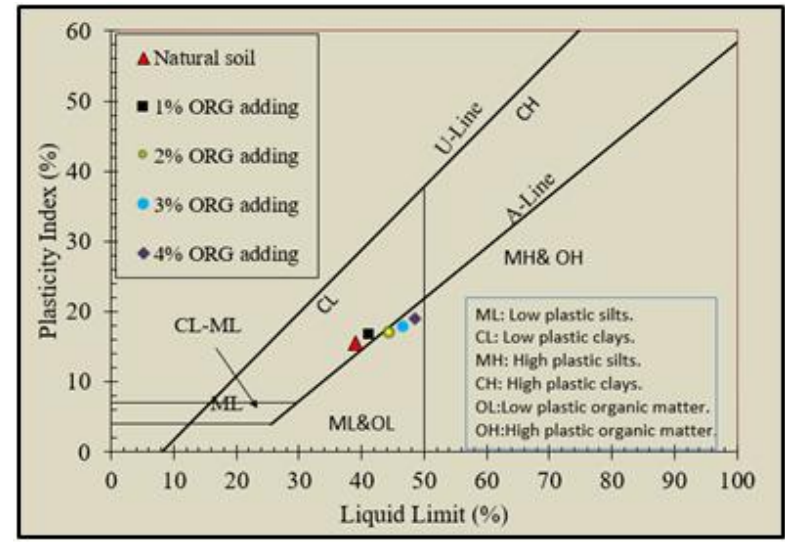

Figure3. Plasticity chart for different organic matter percentages

\subsection{Unconfined Compressive Strength}

The unconfined compression strength results for the natural soil and treated samples are 713.37, $705.08,679.40,634.11$ and $540.23 \mathrm{kPa}$, respectively. The results show that there is a significant decrease in the values of unconfined compressive strength by increasing the percentages of organic content, as shown in Figure 4. The unconfined compressive strength decreases 1.17,5,12.5 and 32\%, respectively in $1,2,3$ and $4 \%$ of the organic matter add with compared to the natural soil.

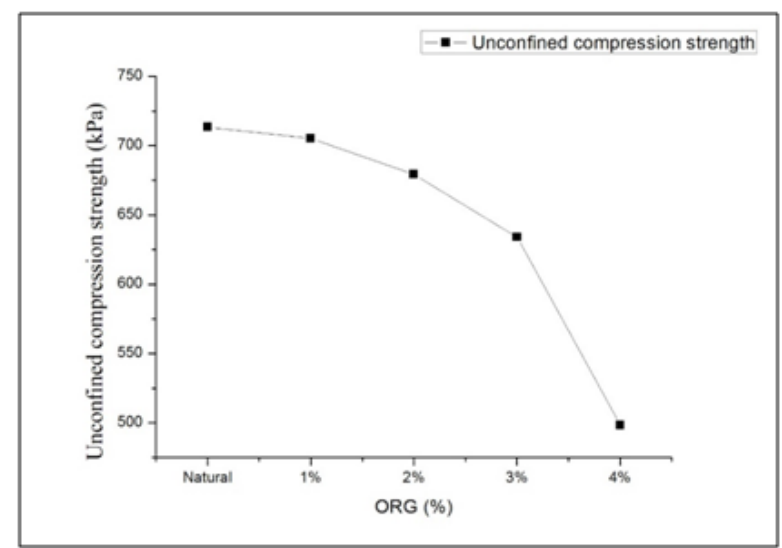

Figure4. The unconfined compressive strength with different organic matter proportions

The decreasing in the values of unconfined compressive strength with increasing organic matter is due to the reaction between organic matter molecules and soil particles during 7-day curing periods. As a result of this reaction the chemical bonds that formed between the organic and soil components were destroyed, therefore these components transformed into a carboxylic acid, which has a high solubility in water (Ali, 2010). The solubility of organic matter with water leads to forms of organic acids, these acids will oxides the organic carbon, therefore reduced the soil strength (Baver,1972).

\subsection{Direct Shear Test}

The results of the test show that the shear strength for the natural soil and treated samples are $40,36,34,39$ and $26 \mathrm{kN} / \mathrm{m}^{2}$, respectively. While, the cohesion test results for the natural soil and treated soil samples are $36,34,28,22$ and $18 \mathrm{kPa}$, respectively. The result shows that there is a high decrease in the values of cohesion (c) by increasing the organic matter content. The cohesion values are decreased from $36 \mathrm{kPa}$ at the natural soil to $18 \mathrm{kPa}$ at the soil containing $4 \%$ of the organic matter 
added, as in Figure 5. Also, the angle of internal friction of treated soils was highest in the 1\% and 2\% the organic matter added compared with the natural soil and it is a decrease in the $3 \%$ and $4 \%$ of the organic matter added, as shown in figure 6.

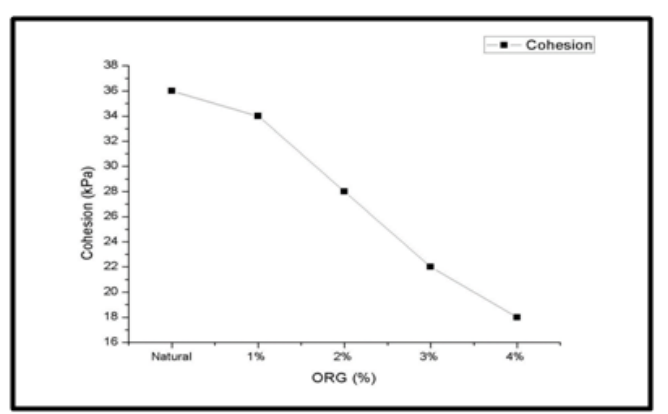

Figure5. The cohesion of natural soil and soil with different percentage of organic matter

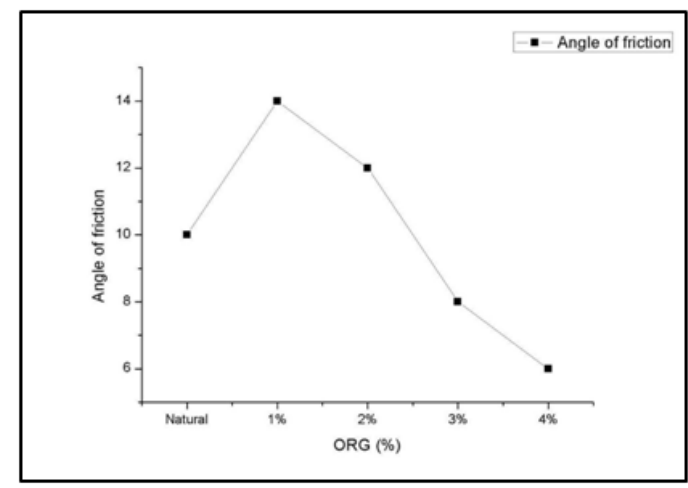

Figure6. The angle of internal friction of natural soil and soil with different percentage of organic matter

It seems from figure 5 above that there is a significant decrease in the cohesion values with increasing organic matter content. This is due to the presence of high amount of organic matter (animal manure) work on isolating the soil granules from each other and weakens the bonds them. The manure molecules surround the soil molecule, which led to a decrease in the values of the cohesion for this studied soil. Figure 6 shows that there is an increase in the values of angle of internal friction with 1 and $2 \%$ of the organic matter added, this increase is due to the organic matter acting as a binding agent between the pore space compared to the natural soil and it is decreased in the 3 and $4 \%$ of the organic matter added, this decrease is due to the high amount of organic matter that can absorb a high amounts of water, thus the soil moisture will be increase and helps the soil particles to slid to each other.

\section{CONClusion}

The study shows the following conclusions:

1. There is a gradual increase in the values of liquid limits and plasticity index with increasing organic matter content.

2. The unconfined compression strength decreases with an increasein organic matter contents.

3. The cohesion valuesdecrease with the increase in organic matter content.

4. There is a significant decrease in the values of unconfined compression strength and cohesion with 3 and $4 \%$ of the organic matter add. This decreasehas a significant effect on engineering soil behavior.

\section{REFERENCES}

[1] Ali, H.H. (2010). The Effect of Some Chemical and Organic Materials on Some Engineering Properties of soil. Journal of Engineering and Technology, Vol. 28, No22, 2010.

[2] ASTM Standard D 1883 - 99, Standard Test Method for CBR (California Bearing Ratio) of LaboratoryCompacted Soils. West Conshohocken, PA: ASTM International.

[3] ASTM Standard D 2166-00, Standard Test Method for Unconfined Compressive Strength of Cohesive Soil. 
[4] ASTM Standard D 3080, Standard Test Method for Direct Shear Test of Soils Under Consolidated Drained Conditions.

[5] ASTM Standard D 4318, 2005, Standard Test Methods for Liquid Limit, Plastic Limit, and Plasticity Index of Soils, Vol. 04.08.

[6] Bal dock, JA, andSkjemstad, JO. (1999). Soil Organic Carbon /Soil Organic Matter. In Peverill, KI, Sparrow, LA and Reuter, DJ (eds). Soil Analysis - an Interpretation manual. CSIRO Publishing Collingwood Australia.

[7] Booth, J. S., \& Dahl, A. G. (1986). A Note on the Relationships Between Organic Matter and Some Geotechnical Properties of MarineSediment.

[8] Mahmood, R.A. (1997). Some Geotechnical Properties of Recent Quaternary Sediments in Basra city, Unpublished MSc. Thesis, College of science, Basra University, 111p. (In Arabic).

[9] Myslinska, E. (2010). Classification of Organic Soils for Engineering Geology. Geological Quarterly, 47(1), 39-42.

[10] Scott, C. R. (1980). Soil Mechanics and Foundations. Applied Science. publishers LTD, London, 406 pp.

[11] Soil Science Society of America, (1979). Joint Transportation Research Program Technical Report FHWA/IN/JTRP-2012/22.

[12] Warrick AW. 2002. Soil Physics Companion. (ed.). CRC Press LLC. Boca Raton, London, New York Washington, D.C. P: 19.

Citation: Alaa Mohsin Khalaf \& Asst. Prof. Rai'd Aziz Mahmood, (2019)" Organic Matter Effects on Some Geotechnical Properties of Cohesive Soils in Selected Areas of Basrah Governorate/Southern Iraq", Southeast Cameroon, International Journal of Mining Science (IJMS), 5(1), pp.26-30, DOI: http://dx.doi.org/10.20431/2454-9460.0501004

Copyright: (C) 2019 Authors. This is an open-access article distributed under the terms of the Creative Commons Attribution License, which permits unrestricted use, distribution, and reproduction in any medium, provided the original author and source are credited 